\title{
Nanopyramid-based absorber to boost the efficiency of InGaN solar cells
}

\author{
W. El-Huni, ${ }^{\dagger}$ Y. Halfaya, ${ }^{\dagger}$ S. Karrakchou, ${ }^{\dagger, \ddagger}$ M. Arif, ${ }^{\dagger}$ M.B. Jordan, ${ }^{\dagger, \ddagger}$ R.

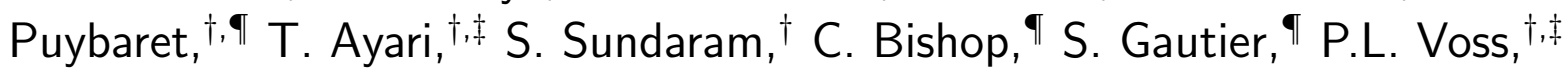 \\ J.P. Salvestrini, ${ }^{*, \dagger}$, and A. Ougazzaden ${ }^{\dagger, \ddagger}$ \\ †UMI 2958 GT-CNRS, Georgia Tech Lorraine, 2 rue Marconi, 57070 Metz, France \\ $\ddagger$ School of Electrical and Computer Engineering, Georgia Institute of Technology, Atlanta, \\ GA 30332-0250, USA \\ هInstitut Lafayette, 3 rue Marconi, 57070 Metz, France \\ E-mail: jean-paul.salvestrini@georgiatech-metz.fr
}

\section{Abstract}

It has been so far difficult to achieve high performance InGaN solar cells even though the band gap of the material system is ideally positioned. One key challenge has been the epitaxial growth of high crystalline quality that contains enough indium $(\gtrsim 15 \%)$ to absorb a significant portion of the solar spectrum while also being thick enough (some tens of $\mathrm{nm}$ ) to absorb strongly. The use of demonstrated nanoselective area growth techniques solve the materials growth problem with demonstrated thick, fully relaxed, and In-rich InGaN nano-pyramid absorbers with extremely high cristalline quality. In this work, we investigate, through simulation, $\mathrm{In}_{0.30} \mathrm{Ga}_{0.70} \mathrm{~N}$ nano-pyramid-based solar cells and we report the first demonstration of InGaN nano-pyramid based solar cells. A comparison of nano-pyramid structures with bulk or MQW structures of equivalent InGaN absorbing volume results in several advantages. The first is that the semi-polar planes of the nanopyramid InGaN absorber reduce polarization charges, which permit lower p-doping. Another advantage is that the $\mathrm{SiO}_{2}$ mask used for the selective area growth helps trap the light, increasing efficiency. The advantage of a carefully designed nano-pyramid solar cell can have an efficiency two orders of magnitude larger than that of a planar InGaN-based solar cell of equivalent absorber volume. The fabricated non optimized solar cell is shown to have larger short circuit photocurrent and open circuit voltage than the state of the art InGaN-based planar solar cell.

\section{Keywords}

InGaN ; Nanopyramids ; Solar cell ; Semi-polar plane ; Polarization charges ; Simulation ; Design 
InGaN-based solar cell performance has been hindered by poor crystalline quality. 1 The growth of high quality thick InGaN layers is difficult mainly due to the formation of extensive crystal defects and phase separation within the layer. ${ }^{2}$ This is unsurprising since the critical layer thickness for a fully strained high quality InGaN with medium In content is only a few nanometers. $\frac{344}{\mathrm{InGaN}}$ based devices with different absorber designs including InGaN bulk layer, ${ }^{5}$ InGaN/GaN semibulk ${ }^{6}$ and superlattice $^{7}$ structures, and InGaN/GaN multiple quantum well (MQWs) PIN structures have been demonstrated. $\stackrel{89}{ }$ However, these architectures evidence a limited indium composition and thickness due to strain, phase separation and 2D to 3D growth mechanisms. Additionally, a significant barrier is present at $\mathrm{GaN} / \mathrm{InGaN}$ heterojunctions, 10 which are detrimental for devices. The best reported efficiency is $5.9 \% 11$ and has been obtained for MQW structure with a total InGaN absorber thickness of $46 \mathrm{~nm}$ and an In content of $19 \%$.

Thus, new design concepts are required for the growth of fully relaxed, high crystalline quality, In-rich InGaN absorbers. One approach, the use of core-shell (coaxial) nanowires $\frac{12[13}{10}$ appeared to be beneficial for InGaN MQW solar cells. Nevertheless, due to some issues with the uniformity of the nanowires and partial coalescence of the $\mathrm{p}$ type layer on top on the nanowires, the highest reported efficiency is $0.3 \%$.

In this paper, we investigate the possible use of InGaN nano-structures grown using a nano selective area growth (NSAG) technique that can overcome the previously mentioned issues. NSAG has been first proposed for significantly extending the critical layer thickness of pseudomorphic growth in mismatched heterostructures. ${ }^{[14}$ For InGaN, NSAG material has been recently shown to be free of dislocations even at high indium incorporation (up to 40\%) 15-17 In this work, we study the design of InGaN nano-pyramids (NP) for solar cell applications to give guidelines for achieving a highefficiency NSAG $\operatorname{In}_{0.30} \mathrm{Ga}_{0.70} \mathrm{~N}$-based solar cell. Using coupled optical and electrical simulation tools (see Figure 1), we compute and compare the electro-optic performances of both planar and nano-structured InGaN absorber-based solar cell in AM1.5G solar spectrum conditions. We also experimentally demonstrate the first proof-of-concept of such a NSAG grown InGaN absorber-based solar cell.

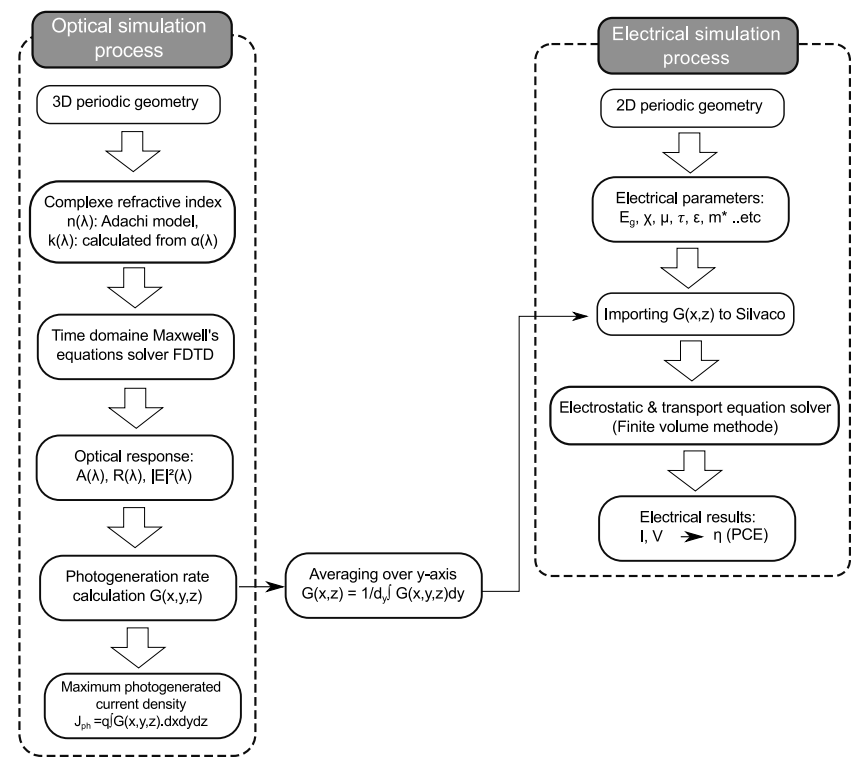

Figure 1: Coupled optical-electrical simulation flowchart. The output of the optical responses, via spatial information of charge generation rate, is used as the input for the electronics modeling. $\mathrm{A}(\lambda)$ is the absorption, $\mathrm{R}(\lambda)$ is the reflection, $|E|^{2}$ is the electric field intensity, $\mathrm{G}(\mathrm{x}, \mathrm{y}, \mathrm{z})$ is the photo-generation, $\mathrm{Eg}$ is the electronic band gap, $\mu$ is the charge mobility, $\epsilon$ is the permittivity, $\mathrm{m}^{*}$ is the charge effective mass, $\chi$ is the work function, $J_{p h}$ is the photo-current density, $\mathrm{V}$ is the voltage, and $(\mathrm{x}, \mathrm{y}, \mathrm{z})$ is the three-dimensional spatial coordinates. Unless specified, all optoelectronic modeling is based on 3D simulation.

\section{Results and discussion}

\section{Solar cell simulation}

The hetero-junction solar cell structure under consideration is shown in figure 2. It is a PIN structure where the $\mathrm{P}$ - and N-regions are made of $\mathrm{Mg}$ doped and Si doped GaN layer. The Iregion corresponds to the absorber which is an array of InGaN NP separated by a $\mathrm{SiO}_{2}$ mask. For simulation purpose, it is described by a primitive cell, as defined in figure Figure 3-(a), 


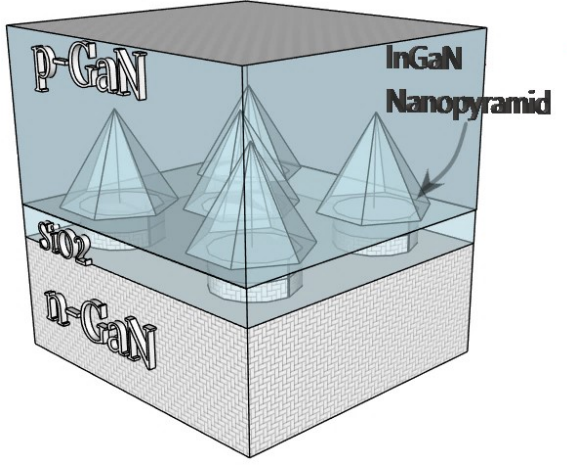

Figure 2: Schematic of the 3D view of the solar cell under consideration.

with periodic boundary conditions in both $\mathrm{x}$ and $\mathrm{y}$ - directions. The parameters of the modeled structure are described in Figure 3-(b) and Figure 3-(c), giving a top view of the primitive cell (with and without InGaN top pyramid) and a cross-sectional view of a single NP, respectively. Photocurrent density $\mathrm{J}_{p h}$ is mostly used (a)

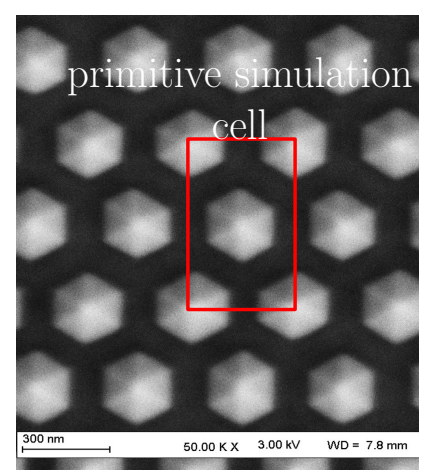

(b)

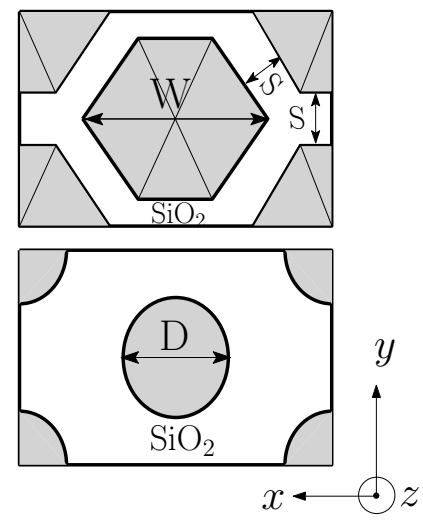

Figure 3: (a) SEM image of the InGaN NP array where the primitive modeled cell is indicated by the red color box. (b) Top view of the modeled structure with (top) and without (bottom) InGaN pyramid. c) Crosssectional view of the single NP modeled structure. to measure the light harvesting capability of a solar cell assuming that every absorbed photon leads to an exciton separation followed by a successful carrier collection. We first used the three-dimensional (3D) Finite-Difference TimeDomaine (FDTD) in Lumerical to model the light-matter interaction and compute the dependence of the absorption, photo-generation rate and ideal photo-current at each node of the structure (see Figure 1 and supplementary material) with the p-GaN layer thickness (d), width of the NP (W) and pyramid spacing $(\mathrm{S})$. Figure 4 shows the ideal photo-current density $J_{p h}$ as function of the spacing between NP varying in the range $0 \mathrm{~nm} \leqslant \mathrm{~S} \leqslant 80 \mathrm{~nm}$ and width of $\mathrm{NP}$ varying in the range $1.25 \times \mathrm{D}$ (to avoid holes overlap) $\leqslant W \leqslant 2 \times D$, mapped for four different hole diameters varying between $80 \mathrm{~nm}$ and 170 nm in the $\mathrm{SiO}_{2}$ mask (D). The p-GaN top layer thickness has been optimized for each couple of parameters $(\mathrm{S}, \mathrm{W})$ to get the highest possible $J_{p h}$. Since increasing $\mathrm{W}$ or decreasing $\mathrm{S}$ lead
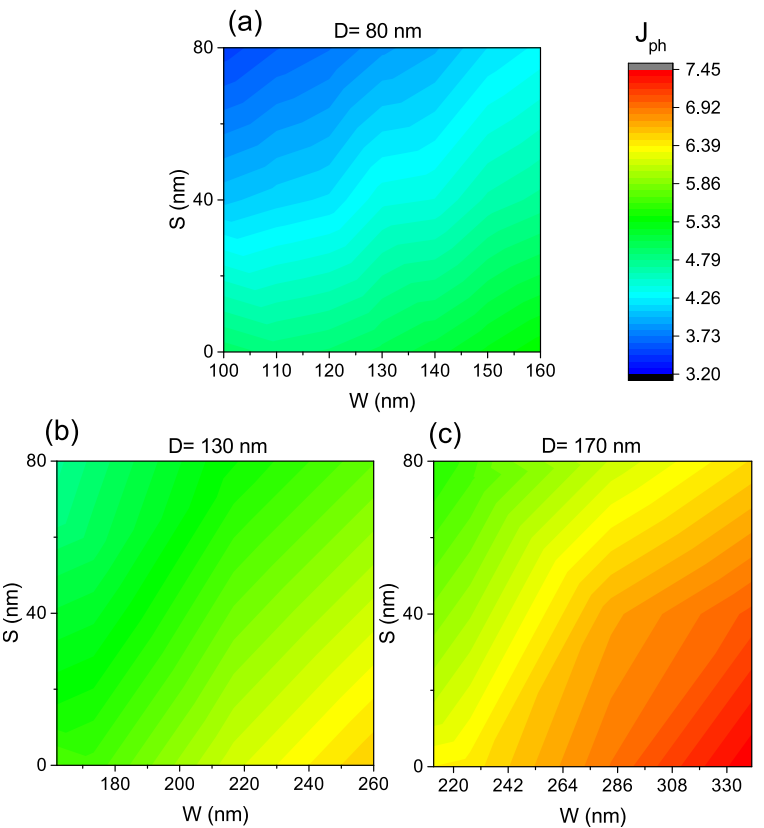

Figure 4: Photo-current density $J_{p h}$ as function of the spacing between NP (S) and width of NP (W) mapped for three different hole diameter in the $\mathrm{SiO}_{2}$ mask: (a) $\mathrm{D}=80 \mathrm{~nm}$, (b) $\mathrm{D}=130 \mathrm{~nm}$, (c) $\mathrm{D}=170 \mathrm{~nm}$. The p-GaN top layer thickness has been optimized to get the highest possible $J_{p h}$.

to a thicker effective planar InGaN layer then $J_{p h}$ increases correspondingly from $3.2 \mathrm{~mA} / \mathrm{cm}^{2}$ 
(for $\mathrm{D}=80 \mathrm{~nm}, \mathrm{~S}=80 \mathrm{~nm}, \mathrm{~W}=100 \mathrm{~nm}$ ) up to $7.45 \mathrm{~mA} / \mathrm{cm}^{2}$ (for $\mathrm{D}=170 \mathrm{~nm}, \mathrm{~S}=0 \mathrm{~nm}, \mathrm{~W}=340$ $\mathrm{nm})$. As expected, densely packed and large NP are preferable to obtain large $J_{p h}$.

In order to have more insights on the role of the p-GaN thickness, Figure 5-(a) shows the variation of $J_{p h}$ as function of both the p-GaN top layer thickness and width of the NP for a hole diameter in the $\mathrm{SiO}_{2}$ mask $\mathrm{D}=170 \mathrm{~nm}$ and for a spacing between the NP equal to zero, which corresponds obviously to the largest InGaN absorber effective thickness (total InGaN NP volume distributed on a planar layer having the surface area of the solar cell) and thus highest optical absorption and $J_{p h}$. The variation of $J_{p h}$ with $d$ or $W$ is not monotonic. The presence of maxima and minima in the dependence of $J_{p h}$ can be explained by a modulation of the optical reflection at the top surface of the solar cell induced by the interference phenomenon between the optical waves reflected at the top surface and at the $\mathrm{p}-\mathrm{GaN} / \mathrm{SiO}_{2}$ interface, respectively. As seen in Figure 5-(b), this effect gives rise, for a p-GaN top layer thickness of $220 \mathrm{~nm}$, to an increase of the absorption in a wider range of wavelength than for $\mathrm{p}-\mathrm{GaN}$ top layer thickness of $180 \mathrm{~nm}$, leading to an enhancement of $J_{p h}$ by $12 \%$ for a p-GaN top layer thickness of 220 $\mathrm{nm}$.

To compare the performance of the InGaN NP absorber-based solar cell with those of the planar InGaN absorber-based solar cell whose absorber thickness is an effective thickness corresponding to the volume of the InGaN NP, Figure 6-(a,b) shows the $J_{p h}(W, D)$ maps obtained in both cases for an optimized p-GaN top layer thickness and a spacing between the $\mathrm{NP} \mathrm{S}=0 \mathrm{~nm}$. As expected, for both devices, $J_{p h}$ increases with both $\mathrm{W}$ (more markedly) and $\mathrm{D}$ since this corresponds to an increase of the effective InGaN absorber thickness. Nevertheless, for a width of NP larger than 170 $\mathrm{nm}$ (corresponding to an effective thickness of around $55 \mathrm{~nm}), J_{p h}$ becomes higher in the case of the InGaN NP absorber-based solar cell, and reaches, for an effective InGaN thickness of around $95 \mathrm{~nm}$ (corresponding to $\mathrm{W}=340 \mathrm{~nm}$ and $\mathrm{D}=170 \mathrm{~nm}$ ), a value of about $7.4 \mathrm{~mA} / \mathrm{cm}^{2}$ corresponding to an increase of $9 \%$. This orig-
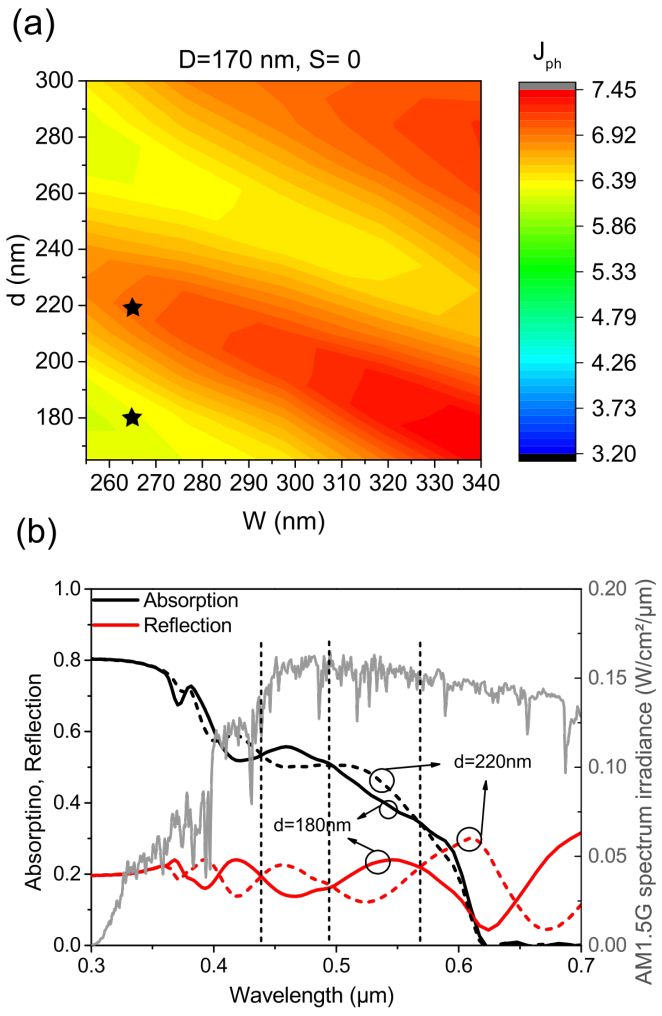

Figure 5: (a) Photo-current density $J_{p h}$ as function of the p-GaN top layer thickness and width of the NP for a hole diameter in the $\mathrm{SiO}_{2}$ mask $\mathrm{D}=170 \mathrm{~nm}$ and for a spacing between the NP equal to zero. (b) Dependence of the absorption and reflection spectra for two p-GaN top layer thicknesses (located by the two stars in (a)), a hole diameter in the $\mathrm{SiO}_{2}$ mask $D=170 \mathrm{~nm}$, and a spacing $S=0$.

inates from an increase of the absorption (see Figure 6-(c)) which can be explained by a lighttrapping effect in the NP due to the nanostructured $\mathrm{SiO}_{2}$ mask, as evidenced below.

Figure 7 compares the cross section maps of the optical electric field intensity obtained at a wavelength $\lambda=525 \mathrm{~nm}$ and for the three cases marked @1 and @2 (InGaN NP absorber-based solar cell), and @3 (planar InGaN absorberbased solar cell) in Figure 6. A periodic vertical optical electric field intensity pattern, originating from the interference effect mentioned previously, is observed in the three cases. This pattern is more intense for the InGaN NP solar cell (Figure 7-(a) and -(b)) because of the larger refractive index contrast at the interface between the $\mathrm{SiO}_{2}$ mask and the InGaN NP, compared to a planar InGaN solar cell (Figure 7 . 


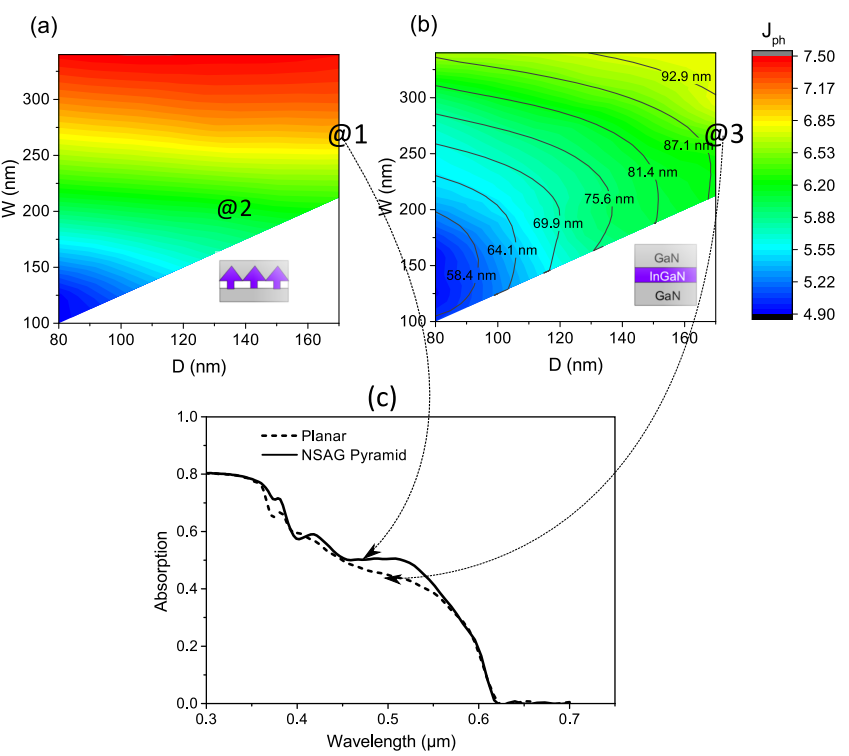

Figure 6: (a,b) $J_{p h}(W, D)$ maps of the InGaN NP absorber-based solar cell and planar InGaN absorberbased solar cell whose absorber thickness is an effective thickness corresponding to the volume of the InGaN $\mathrm{NP}$, for an optimized p-GaN top layer thickness and a spacing between the NP $\mathrm{S}=0 \mathrm{~nm}$. The lines in (b) indicate the corresponding effective planar InGaN layer thickness. (c) Absorption spectra obtained for both devices having the same effective InGaN thickness and an optimized p-GaN layer thickness.

(c)) for which the p-GaN/InGaN interface has a weaker refractive index contrast. In the case of the InGaN NP solar cell, it is also more intense for large $\mathrm{W}$ and $\mathrm{D}$ because of the broader $\mathrm{SiO}_{2} /$ InGaN interface. The light-trapping in the NP is clearly seen in Figure 7. (a) showing a large optical confinement in the base of the NP and a less pronounced one in the upper part of the NP. It is to be noticed that this confinement disappears for the smaller size NP (Figure 7-(b)) because of the wavelength of the light which is probably above the cut-off wavelength allowing the optical confinement. This optical confinement is probably generated by the horizontal sub-wavelength grating mirror $\left(\mathrm{SiO}_{2}\right.$ mask with holes filled by InGaN material on top of a low refractive index sub-layer $(\mathrm{n}-\mathrm{GaN})) \cdot \frac{18}{18}$

Considering the band gap of the InGaN absorber with $30 \%$ of In content, a maximum photocurrent of $13 \mathrm{~mA} / \mathrm{cm}^{2}$ is expected for AM1.5G solar spectrum conditions. The difference between this value and those of 6.8 (a)
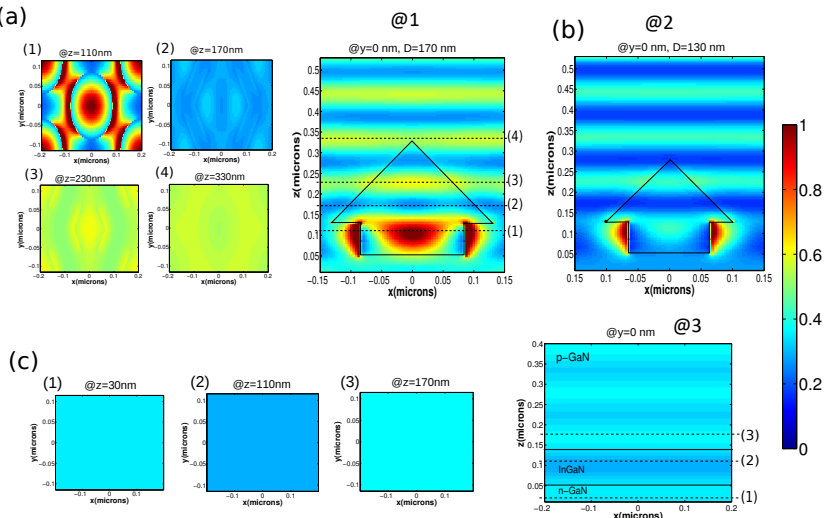

Figure 7: Cross section $(\mathrm{x}, \mathrm{y})$ and $(\mathrm{x}, \mathrm{z})$ maps of the optical electric field intensity obtained at $\lambda=525 \mathrm{~nm}$ for (a) @1 and (b) @2 InGaN NP absorber-based and (c) @3 planar InGaN absorber-based solar cells. See Figure 6 for the @1, @2, @3 marks. Optical absorption has not been taken into account to clearly highlight the light trapping effect.

$\mathrm{mA} / \mathrm{cm}^{2}$ for an opening in the $\mathrm{SiO}_{2}$ mask of $\mathrm{D}=170 \mathrm{~nm}$ and a NP width of $\mathrm{W}=275 \mathrm{~nm}$ (@1 mark in Figure 6) can be explained by either the reflection at the front surface which is about $20 \%$, and partial absorption due to the limited effective thickness of the InGaN absorber which is about $89 \mathrm{~nm}$ in this case. Therefore, if we consider, as proposed by Dahal et al., $\frac{19}{19}$ an anti-reflective coating (ARC) and a dielectric mirror (DM) on the top and bottom of the solar cell, respectively, the solar cell absorption spectrum can be tuned in such a way that the photocurrent is increased by $26 \%$ to reach $9.2 \mathrm{~mA} / \mathrm{cm}^{2}$, as shown in Figure 8-(a). The ARC design used in our simulation as well as its reflection spectrum, which is close to those achieved by Young et al. ${ }^{20}$ is shown in Figure 8 . (b) Instead of using a DM which is difficult to achieve with broadband performance, we can use a $100 \mathrm{~nm}$ thick silver reflective layer whose reflection spectrum is also shown in Figure 8. (b). Further work to implement an optimized DM mirror with the highest possible reflection in the $350 \mathrm{~nm}-620 \mathrm{~nm}$ range, which is advantageous for the combination of high band gap InGaN-based solar cells with silicon, as we have shown in previous work, $\stackrel{21}{21}$ in in progress.

To further assess the InGaN NP absorberbased solar cell performance, we have con- 

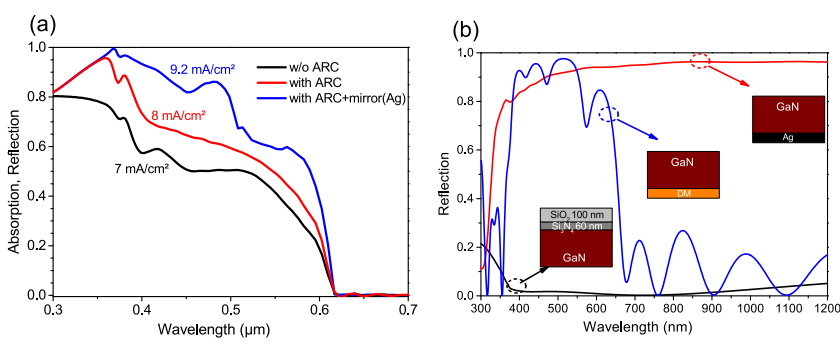

Figure 8: (a) Tuning solar cell absorption spectrum using (b) a multi-layered $\mathrm{SiO}_{2} / \mathrm{Si}_{x} \mathrm{~N}_{x}$ anti-reflection coating at its top and a metallic mirror (Ag layer) at its bottom. The blue curve shows the reflection spectrum of the DM constituted of two multi-layered $\mathrm{Si}_{3} \mathrm{~N}_{4} / \mathrm{SiO}_{2}$ and $\mathrm{Ta}_{2} \mathrm{O}_{5} / \mathrm{MgF}_{2}$ stacks.

ducted 2D electrical simulation using Silvaco software which does not solve properly 3D 6faceted pyramids. For that, we have produced a $2 \mathrm{D}$ photo-generation rate map, based on the optimized parameters described above, from the $3 \mathrm{D}$ photo-generation rate map by flattening it along the y-axis using a spatial averaging which almost allows for the conservation of the total photo-generated carriers throughout the volume of the NP. ${ }^{22}$ Then, this approximated 2D map serves as input data for 2D electrical simulations. Figure 9-(a) shows such a 2D photogeneration map using the optimized geometric parameters and for AM1.5 illumination conditions. The photo-generation rate is larger in
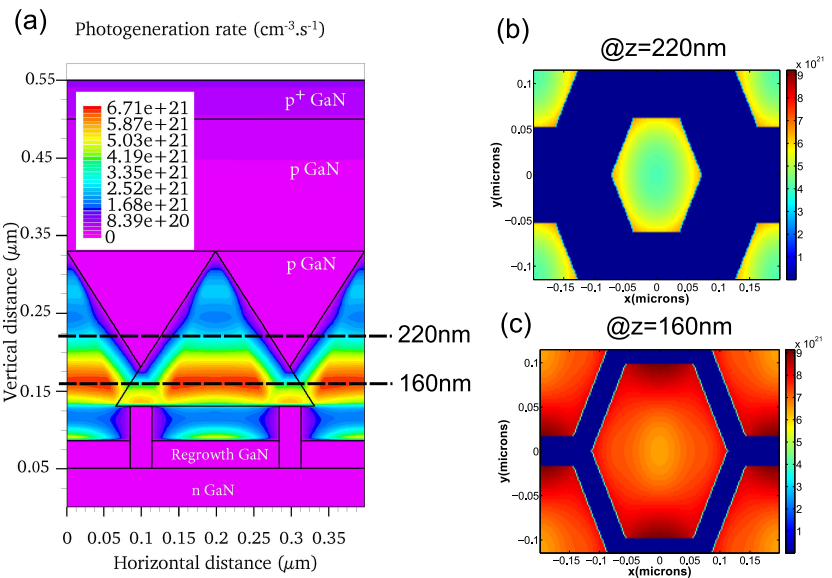

Figure 9: a) 2D photo-generation map calculated from the $3 \mathrm{D}$ photo-generation map using the optimized geometric parameters and for AM1.5 illumination conditions. Cross section of the 3D photo-generation map at a NP height of (b) $160 \mathrm{~nm}$ and (c) $220 \mathrm{~nm}$.

the down part than in the upper part of the
NP. This is due to both the larger volume and optical electric field intensity of the InGaN absorber in the down part of the NP as show in Figure 9-(b) and Figure 9-(c). It is to be noticed that the value of $\mathrm{J}_{p h}$ calculated using Silvaco and the approximated $2 \mathrm{D}$ map is equal to $9.165 \mathrm{~mA} / \mathrm{cm}^{2}$ for a defect-free device. This value is very close to the one obtained from the 3D map using Lumerical $\left(9.2 \mathrm{~mA} / \mathrm{cm}^{2}\right.$, see Figure 8 confirming the the validity of the approximation made.

The geometrical parameters (opening diameter in the $\mathrm{SiO}_{2}$ mask, thickness of the p-GaN layer, ARC coating, back mirror) of the solar cell being optimized, we have studied the role of both the p-GaN, u-InGaN and n-GaN doping on the solar cell performance. To achieve high efficiency InGaN solar cells a high level of doping for the $\mathrm{p}-\mathrm{GaN}$ and $\mathrm{n}-\mathrm{GaN}$ layers is required to limit the barrier height at the heterointerfaces, while low u-InGaN residual doping is needed ${ }^{23}$ to keep the width of the depletion region as large as possible. These requirements are all the more crucial as the discontinuity in spontaneous and piezoelectric polarization generates interface charges that produce supplementary and strong band bending and potential barriers as well as electric field that hinders separation of photo-generated carriers. $24+26$ If highly doped n-GaN layer can be grown relatively easily, 2728 the growth of highly p-type GaN layers remains difficult $\frac{29}{29}$ and the undoped InGaN typically demonstrates n-type conductivity resulting from a high background concentration. 30

Figure 10-(a) and Figure 10-(b) shows the dependence of the power conversion efficiency (PCE) as function of the n-GaN and $\mathrm{p}-\mathrm{GaN}$ doping concentration for both InGaN NP absorber-based and planar InGaN solar cells and for a residual donor concentration in the InGaN layer of $8 \times 10^{16} \mathrm{~cm}^{-3}$. As it can be seen and as expected, a maximum PCE of $10.8 \%$ can be obtained for a n-GaN doping concentration larger than $8 \times 10^{19} \mathrm{~cm}^{-3}$ whatever the solar cell structure (InGaN NP or planar In$\mathrm{GaN}$ ). As mentioned above, this is due to the large barrier in the conduction band at the n$\mathrm{GaN} / \mathrm{InGaN}$ hetero-interface which is the same 

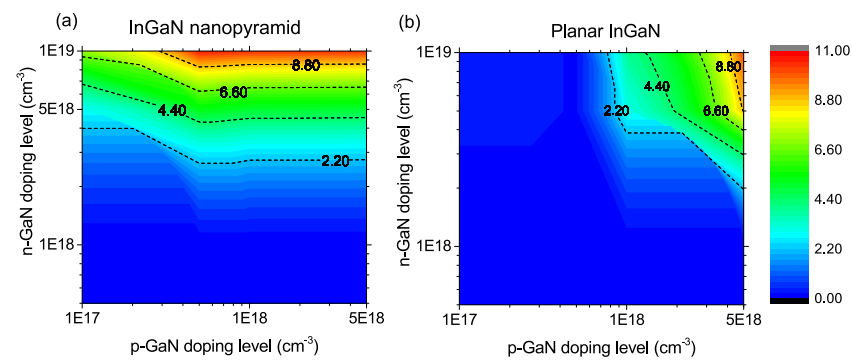

Figure 10: Dependence of the PCE with respect to either n-GaN and p-GaN doping concentrations for both (a) InGaN NP absorber-based and (b) planar InGaN solar cells.

for both structures, and can be lowered by increasing the n-GaN doping concentration, as shown in Figure 11-(a), leading to the accumulation of a large positive charge in the n-GaN region close to the interface causing an inversion layer in the InGaN layer which in turn leads to the screening of the the polarizationinduced charges (see Figure 11-(b)). On the other hand, it is to be noticed that the constraint on the p-GaN doping concentration is highly relaxed in the case of the InGaN NP absorber-based solar cell when compared to the planar InGaN solar cell. Indeed, to reach the maximum PCE, the required p-GaN doping concentration is one order of magnitude less in the InGaN NP absorber-based solar cell than in the planar InGaN solar cell $\left(5 \times 10^{17} \mathrm{~cm}^{-3}\right.$ instead of $\left.5 \times 10^{18} \mathrm{~cm}^{-3}\right)$. This is due to the fact that the $\mathrm{p}-\mathrm{GaN} / \mathrm{InGaN}$ interface in the case of the InGaN NP is along the r-planes which induce much less polarization charges effect. Thus, as seen in Figure 12, a p-GaN doping concentration of $1 \times 10^{18} \mathrm{~cm}^{-3}$ allows for an accumulation of negative charges in the $\mathrm{p}-\mathrm{GaN}$ region which is enough to create an inversion layer, and thus an electric field allowing the separation of the photo-carriers, in the InGaN layer in the case of the InGaN NP solar cell. In the case of the planar InGaN solar cell, for the same accumulation of negative charges in the $\mathrm{p}-\mathrm{GaN}$ region, the polarization charge effect is stronger ( $\mathrm{p}-\mathrm{GaN} / \mathrm{InGaN}$ interface along the c-planes), leading to the accumulation of negative charges in the InGaN region and creation of an electric field that hinders separation of photo-generated carriers.
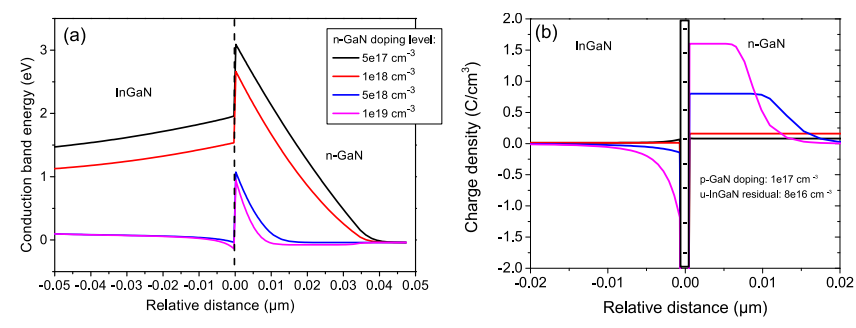

Figure 11: (a) Conduction band and (b) charge distribution at the n-GaN/InGaN hetero-junction for different level of the n-GaN doping concentration.
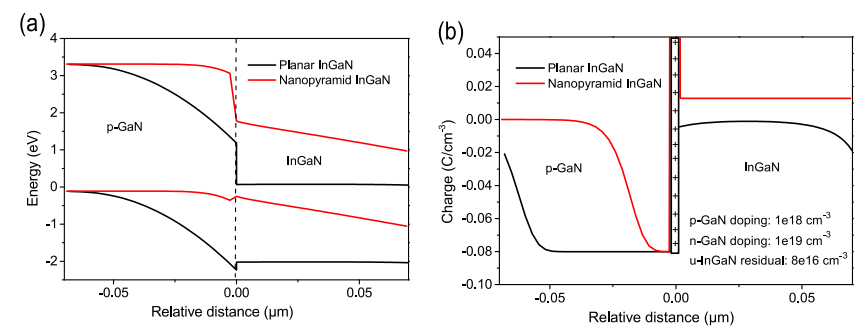

Figure 12: (a) Energy band diagram and (b) charge distribution at the p-GaN/InGaN hetero-junction for both InGaN NP absorber and planar InGaN based solar cells.

To conclude the study of the role of doping, Figure 13 shows the dependence of the PCE with the residual donor concentration of the InGaN layer for both InGaN NP absorber-based and planar InGaN solar cells and for different p-GaN doping concentration, and with a n-GaN doping concentration of $1 \times 10^{19} \mathrm{~cm}^{-3}$. For residual donor concentration of the $\mathrm{InGaN}$ layer up to around $1 \times 10^{17} \mathrm{~cm}^{-3}$, the PCE exhibits slight variations (increase or decrease) whatever are the p-GaN doping concentration and the type of solar cell. The slight increase of the PCE can be explained by the increase of the $\mathrm{V}_{o c}$ due to to the shrinking of the space charge region ${ }^{31}$ while the $\mathrm{J}_{s c}$ remains constant. Beyond this residual concentration level a decrease of the PCE can be noticed especially in the case of the InGaN NP absorber-based solar cell with a p-GaN doping concentration of $5 \times 10^{17} \mathrm{~cm}^{-3}$. This can be explained by the fact that the overlap between the region where the photo-generation rate is high (see Figure 9) and the region where the drift electric field is high (see Figure 13-b,c) becomes weaker, especially for a high residual donor concentration of the InGaN layer (see Figure 13-c). This phenomenon is even stronger 
because of the diffusion length of the photocarrier which becomes smaller with the increase of the residual donor concentration. Finally, Figure 13-(a) shows that InGaN NP absorberbased solar cells can tolerate a higher InGaN residual donor concentration that the planar InGaN solar cells. (a)

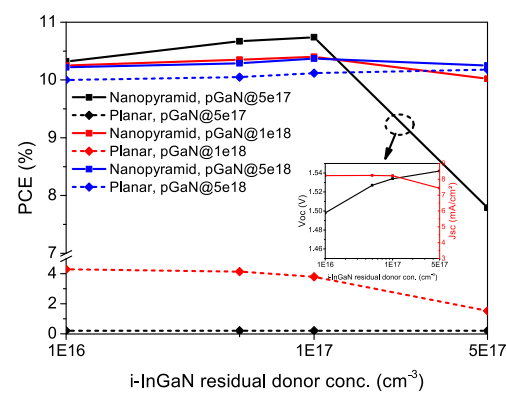

(b)

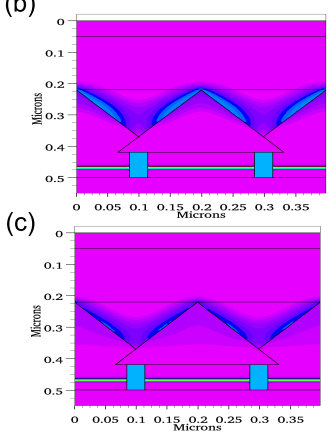

Figure 13: (a) Dependence of the PCE with respect to the residual donor concentration of the InGaN layer for both InGaN NP absorber-based and planar InGaN solar cells and for different p-GaN doping concentration with a n-GaN doping concentration of $1 \times 10^{19} \mathrm{~cm}^{-3}$. The inset shows both the $\mathrm{J}_{s c}$ and $\mathrm{V}_{o c}$ dependence with the residual donor concentration of the InGaN layer. Electric field map in the InGaN NP absorber-based solar cell for two different residual donor concentration of the InGaN layer: (b) $5 \times 10^{17} \mathrm{~cm}^{-3}$ and (c) $1 \times 10^{17} \mathrm{~cm}^{-3}$ and a p-GaN doping concentrations of $5 \times 10^{17} \mathrm{~cm}^{-3}$.

As shown in Table 1, the $\operatorname{In}_{0.3} \mathrm{Ga}_{0.7} \mathrm{~N}$ NP absorber-based solar cell, optimized in terms of mask opening, doping, ARC and back mirror, can reach a PCE of $10.8 \%$ using currently available technologies. This value is close to the one obtained by Fabien et al. ${ }^{23}$ who considered a device with similar n-GaN and i-InGaN dopings but with a high p-GaN doping and especially $500 \mathrm{~nm}$ thick planar $\operatorname{In}_{0.3} \mathrm{Ga}_{0.7} \mathrm{~N}$ absorber which is not achievable with a good crystalline quality in contrary to the InGaN NP. Furthermore, the improvements allowed by the latter in terms of reflection and polarization management could lead to the fabrication of a solar cell with a PCE which is twice or triple those of the best achieved InGaN MQWs based device, and even much more when compared to the InGaN MQWs core shell absorber-based solar cell (see Table 1).
Table 1: Performances of InGaN-based solar cells with $30-35 \%$ of In content: Simulated and experimental data.

\begin{tabular}{|c|c|c|c|c|c|c|c|}
\hline $\begin{array}{c}\mathrm{J}_{s c} \\
\left(\mathrm{~mA} / \mathrm{cm}^{2}\right)\end{array}$ & $\begin{array}{l}\mathrm{V}_{o c} \\
(\mathrm{~V})\end{array}$ & $\begin{array}{l}\mathrm{FF} \\
(\%)\end{array}$ & $\begin{array}{l}\mathrm{PCE} \\
(\%)\end{array}$ & $\begin{array}{c}\mathrm{E}_{G} \\
(\mathrm{eV})\end{array}$ & $\begin{array}{l}\text { [In] } \\
(\%)\end{array}$ & Parameters & Reference \\
\hline 8.25 & 1.5 & 86.7 & 10.8 & 2.03 & 30 & $\begin{array}{c}\mathrm{n}=10^{19} \mathrm{~cm}^{-3} \\
\mathrm{p}=5 \times 10^{17} \mathrm{~cm}^{-3} \\
\mathrm{i}=10^{17} \mathrm{~cm}^{-3} \\
\mathrm{D}=170 \mathrm{~nm} \\
\mathrm{~W}=265 \mathrm{~nm} \\
\text { ARC and DM }\end{array}$ & $\begin{array}{l}\text { This } \\
\text { work } \\
\text { Simu- } \\
\text { lation }\end{array}$ \\
\hline $\mathrm{n} / \mathrm{a}$ & $\mathrm{n} / \mathrm{a}$ & $\mathrm{n} / \mathrm{a}$ & 11.5 & 2.25 & 30 & $\begin{array}{c}\mathrm{n}=8 \times 10^{18} \mathrm{~cm}^{-3} \\
\mathrm{p}=4 \times 10^{18} \mathrm{~cm}^{-3} \\
\mathrm{i}=10^{17} \mathrm{~cm}^{-3} \\
500 \mathrm{~nm} \text { thick } \\
\text { planar InGaN }\end{array}$ & $\begin{array}{l}\text { Ref. } \\
\text { Simu- } \\
\text { lation }\end{array}$ \\
\hline 1 & 0.5 & 54 & 0.3 & 2.1 & 33 & $\begin{array}{l}8 \times 4 \mathrm{~nm} \text { InGaN } \\
\text { QWs nanowires } \\
\text { (length: } 900 \mathrm{~nm} \text { ) }\end{array}$ & $\begin{array}{l}\text { Ref.12 } \\
\text { Experi- } \\
\text { mental }\end{array}$ \\
\hline 2.56 & 1.8 & 64 & 2.95 & 2.24 & 35 & $\begin{array}{c}12 \times 3 \mathrm{~nm} \\
\text { InGaN QWs } \\
\text { ARC and DM }\end{array}$ & $\begin{array}{l}\text { Ref.19 } \\
\text { Experi- } \\
\text { mental }\end{array}$ \\
\hline 2.97 & 2.72 & 61.5 & 4.97 & 2.22 & 36 & $\begin{array}{l}20 \times 2.3 \mathrm{~nm} \\
\text { InGaN QWs } \\
\mathrm{ARC} \text { and DM }\end{array}$ & $\begin{array}{l}\text { Ref.11 } \\
\text { Experi- } \\
\text { mental }\end{array}$ \\
\hline
\end{tabular}

\section{Solar cell fabrication and assess- ment}

To assess our approach, $100 \times 100 \mu \mathrm{m}^{2}$ $\mathrm{In}_{0.09} \mathrm{Ga}_{0.91} \mathrm{~N}$ NP based solar cells have been fabricated. Figure 14-(a) shows the patterned $\mathrm{SiO}_{2}$ mask and a cross-sectional schematic view of the device and a top-view SEM image of the fabricated solar cell are presented in Figure 14. (b). The In content in the NP has been chosen for comparison. We have recently achieved $\mathrm{In}_{0.08} \mathrm{Ga}_{0.92} \mathrm{~N}$ semibulk based solar cells with a PCE three times higher than the state of the art. [6 Since the NP based solar cells have been fabricated using the same MOVPE growth machine and technological processes for the metal contact deposition, and characterized using the same measurement setups, than the semibulk solar cells, the comparison makes sense. Due to the small size of the device and low In content in the InGaN NP absorber the photo-current was too low to be measured that is why we used a concentrated UV lamp with a power density of around $140 \mathrm{~mW} / \mathrm{cm}^{2}$ distributed over the 350 $420 \mathrm{~nm}$ wavelength range. Figure 15 shows the corresponding typical voltage dependence of both the dark- and photo-current density measured for the InGaN NP-based solar cell. The values of the short-circuit current $\left(J_{s c}\right)$, opencircuit voltage $\left(V_{o c}\right)$ and fill factor $(\mathrm{FF})$ derived from the measurement are $12.7 \mathrm{~mA} / \mathrm{cm}^{2}, 1.89$ 


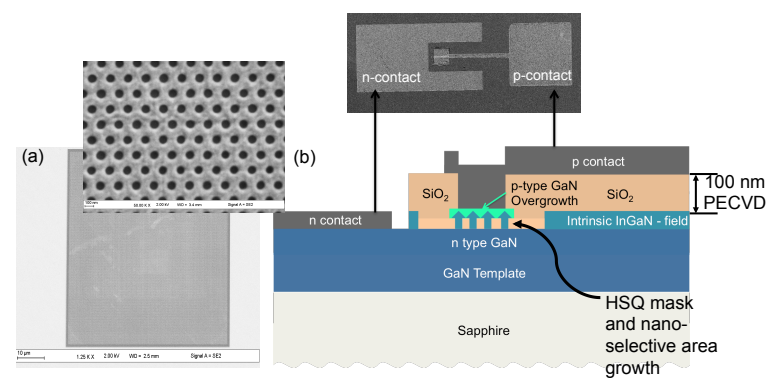

Figure 14: (a) SEM image of the patterned $\mathrm{Si}_{2}$ mask and (b) cross-sectional schematic view of the device with a top-view SEM image of the fabricated solar cell.

$\mathrm{V}$ and 20\% respectively. As shown in Table 2

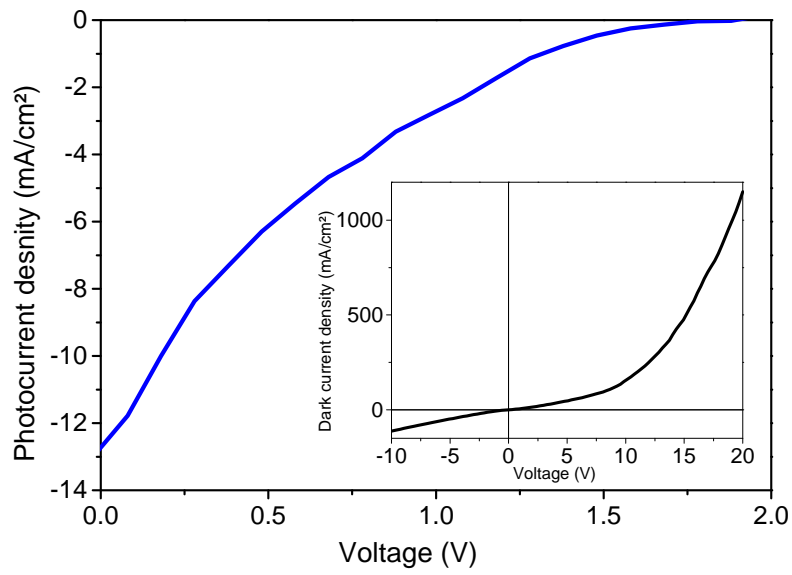

Figure 15: Dependence of both the dark- and photocurrent density (under Illumination of concentrated UV light) measured for the InGaN NP-based solar cell.

the $J_{s c}$ is much higher (by 55\%) than the one of the InGaN semibulk-based solar cell. Considering the UV lamp power density spectrum, the band gap of each PV cell and the absorber thickness (effective thickness in the case of the of InGaN NP-based solar cell), an increase of $J_{s c}$ by around $30 \%$ is expected, this even if the InGaN NP absorber is not optimized in terms of NP width and spacing. The larger $J_{s c}$ of the InGaN NP absorber-based solar cell could be attributed to the high crystalline quality of the InGaN in the NP that could also explain the relatively large $\mathrm{V}_{o c}$ ( $80 \%$ of the expected value derived from the band gap) when compared to the one of the semibulk absorber based solar cell $(60 \%$ of the expected value derived from the band gap). Last, the fill factor of both solar cells is low. This is probably due to the use of concentrated light source leading to the
Table 2: Comparison of the performances of $\mathrm{In}_{0.09} \mathrm{Ga}_{0.91} \mathrm{~N}$ NP absorber-based and $\mathrm{In}_{0.08} \mathrm{Ga}_{0.92} \mathrm{~N}$ semibulk absorber-based solar cells measured under concentrated UV light.

\begin{tabular}{|c|c|c|c|c|}
\hline $\begin{array}{c}\mathrm{J}_{s c} \\
\left(\mathrm{~mA} / \mathrm{cm}^{2}\right)\end{array}$ & $\begin{array}{l}\mathrm{V}_{o c} \\
(\mathrm{~V}) \\
\end{array}$ & $\begin{array}{l}\mathrm{FF} \\
(\%)\end{array}$ & Parameters & Reference \\
\hline 12.7 & 1.89 & 20 & $\begin{array}{c}\mathrm{In}_{0.09} \mathrm{Ga}_{0.91} \mathrm{~N} \mathrm{NP}, \\
\mathrm{D}=100 \mathrm{~nm}, \mathrm{~S}=20 \mathrm{~nm} \\
46 \mathrm{~nm} \text { effective } \\
\text { thickness }\end{array}$ & $\begin{array}{l}\text { This } \\
\text { work }\end{array}$ \\
\hline 8.2 & 1.52 & 30 & $\begin{array}{c}144 \mathrm{~nm} \text { thick } \\
\mathrm{In}_{0.08} \mathrm{Ga}_{0.92} \mathrm{~N} \\
\text { semibuk structure }\end{array}$ & Ref. 6 \\
\hline
\end{tabular}

enhanced carrier recombination at the interface region due to high carrier densities under concentrated UV light. 19

\section{Conclusion}

We have investigated the performance, through simulation, of $\operatorname{In}_{0.30} \mathrm{Ga}_{0.70} \mathrm{~N}$ NP-based solar cells. When compared to planar (bulk or MQW) InGaN absorber, such a nanostructured absorber is shown to release the usual challenging constraint on the doping of the p-GaN layer, which would be needed to overcome the polarization-induced electric field. Such a NP-based solar cell can handle ten times less p-GaN doping while maintaining the same performance. This originates from the hetero-interface junction which lies on the semi-polar planes leading to much less polarization charges. Furthermore, the $\mathrm{SiO}_{2}$ mask used for the selective area growth of the nanopyramids is shown to help trap light into the nano-pyramids leading to a larger optical absorption and thus efficiency. An increase of about $9 \%$ of the photocurrent density is obtained in the NP-based solar cells when compared to the planar structure with the same volume of absorber. A careful design of the InGaN nano-pyramid-based solar cell leads to an efficiency which can reach up to almost two order of magnitude larger than that of a planar InGaN-based solar cell. We also show the very first demonstration of an InGaN nano-pyramid based solar cells. As a proof of concept a fabricated non optimized solar cell is shown to have 
larger short circuit photocurrent and open circuit voltage than a state of the art InGaN-based planar solar cell.

\section{Method}

\section{Optical model}

We have used three-dimensional (3D) FiniteDifference Time-Domaine (FDTD) using Lumerical TCAD software in order to model the light-matter interaction and calculate the photo-generation rate at each node of the structure. The FDTD is a time-consuming method (several days to achieve an optimization of one parameter) compared to other electro-magnetic computational methods like RCWA (Rigourous Coupled Wave Analysis). However, the particularity of our hexagonal pyramid-shaped structure required the use of a FDTD method.

The absorption coefficients $\alpha$ for InGaN alloys were calculated using the following equation: $\frac{32}{32}$

$$
\alpha\left(\mathrm{cm}^{-1}\right)=1 \times 10^{5} \times \sqrt{a \times\left(E-E_{g}\right)+b \times\left(E-E_{g}\right)^{2}}
$$

where $a$ and $b$ are fitting parameters depending on the indium composition. $E$ is the incident photon energy, $E_{g}$ is the bandgap energy which is calculated using the following Vegard's law:

$E_{g}=x \times E_{g}^{I n N}+(1-x) \times E_{g}^{G a N}-b \times x \times(1-x)$

where $x$ is the alloy fraction and $b$ the bowing factor. Refractive index is computed using the model developed by Adachi: $\underline{33}$

$n(\omega)=\sqrt{A(x) \times\left(\frac{E_{g}}{h \omega}\right)^{2} \times\left[2-\sqrt{1+\frac{h \omega}{E_{g}}}-\sqrt{1-\frac{h \omega}{E_{g}}}\right]+B(x)}$

where $\omega$ is the optical frequency, and $A(x)$ and $B(x)$ are fitting parameters depending on the alloy fraction $x$ by:

$$
\begin{gathered}
A(x)=9.827 \times(1+x)-53.57 \times x \\
B(x)=2.736 \times(1-x)-9.19 \times x
\end{gathered}
$$

As we did not find any data in literature concerning the birefringence of InGaN, we have assumed that the material is isotropic in terms of refractive index. Given the sub-wavelength thickness of InGaN NP, the birefringence should have anyway a small effect on the simulation result. The photo-generation rate is extracted by dividing the absorbed power by the photon energy:

$$
g(r, \omega)=\frac{P_{a b s}(r, \omega)}{\hbar \omega}
$$

where $P_{a b s}(r, \omega)$ is the optical power absorbed per unit volume from a monochromatic source at an angular frequency $\omega$ and position $r$, which is obtained by:

$$
P_{a b s}(r, \omega)=-0.5 \times \omega \times|E(r, \omega)|^{2} \times \Im[\epsilon(\omega)]
$$

where $E(r, \omega)$ is the electric field spectral density $\left[V^{2} m^{-2} H z^{-1}\right]$ and $\epsilon$ is the frequency dependent permittivity. The total photo-generation rate is given by the integration over the frequency:

$$
G(r)=\int g(r, \omega) \times d \omega
$$

The photo-generated current $J_{p h}$, estimated with the assumption that each absorbed photon generate a electron-hole pair collected at the electrical contacts, is given by:

$$
J_{p h}=\frac{q}{A} \int G(r) \times d r
$$

where $q$ is the electron charge and $A$ is the primitive cell area. Then, the total photo-generation rate is averaged along the $\mathrm{y}$-direction in order to provide the photo-generation rate map used for 2D Silvaco simulations.

\section{Electrical model}

Due to the large conduction band offset $\left(\Delta E_{c}\right)$ at the InGaN/GaN hetero-interface, we have used the thermo-ionic-field emission carrier transport model proposed by Yang et al. ${ }^{34} \mathrm{We}$ have accounted for Shockley-Reed-Hall (SRH), and surface and radiative recombinations. A surface recombination velocity of $10^{4} \mathrm{~cm} / \mathrm{s}$ for electrons and holes is specified at the front surface. The radiative coefficient and carriers' lifetime can be found here. ${ }^{35}$ As the NSAG 
nanopyramids are considered fully relaxed,,$\frac{16}{}$ we have chosen a bowing factor of $2.59 \mathrm{eV}$ based on the work done by Islam et al. $\stackrel{36}{\text { for }}$ absorption band gap of relaxed InGaN. The same bowing factor has been used to calculate the electron affinity for InGaN. This is based on the study done by Moses et al. ${ }^{37}$ showing that the valence band maximum varies linearly with the indium composition. More details about the physical models and parameters' values can be found here,,$\sqrt{35}$ including electric mobility and effective mass. Table 3 shows some of the commonly accepted parameters used in the simulations.

Table 3: Values of the different parameters used in the simulations

\begin{tabular}{|c|c|c|c|c|}
\hline Parameter & [Unit] & $\mathrm{GaN}$ & $\operatorname{InN}$ & $\begin{array}{l}\text { Interpolation } \\
(\mathrm{InGaN})\end{array}$ \\
\hline $\mathrm{a}$ & {$\left[\mathrm{A}^{o}\right]$} & 3.189 & 3.545 & Linear \\
\hline $\mathrm{c}$ & {$\left[\mathrm{A}^{o}\right]$} & 5.185 & 5.7 & Linear \\
\hline $\mathrm{E}_{g}$ & {$[\mathrm{eV}]$} & $3 . 3 9 \longdiv { 3 6 3 8 }$ & $0.65^{39}$ & Bowing $=2.59 \stackrel{36}{\mathrm{eV}}$ \\
\hline \multicolumn{5}{|c|}{ Recombination } \\
\hline$\tau_{n 0}$ & {$[\mathrm{~s}]$} & $5 \times 10^{-9}$ & $5 \times 10^{-9}$ & \\
\hline$\tau_{p 0}$ & & $5 \times 10^{-9}$ & $5 \times 10^{-9}$ & \\
\hline $\mathrm{C}_{r a d}$ & {$\left[\mathrm{~cm}^{-3} / \mathrm{s}\right]$} & $1 \times 10^{-8}$ & $1 \times 10^{-8}$ & \\
\hline $\mathrm{S}_{n}$ & {$[\mathrm{~cm} / \mathrm{s}]$} & $1 \times 10^{4}$ & $1 \times 10^{4}$ & \\
\hline $\mathrm{S}_{p}$ & {$[\mathrm{~cm} / \mathrm{s}]$} & $1 \times 10^{4}$ & $1 \times 10^{4}$ & \\
\hline \multicolumn{5}{|c|}{ Polarization 40} \\
\hline $\mathrm{P}_{s p}$ & {$\left[\mathrm{C} / \mathrm{m}^{2}\right]$} & -0.029 & $-0,032$ & Bowing $=-0.037$ \\
\hline $\mathrm{e}_{33}$ & {$\left[\mathrm{C} / \mathrm{m}^{2}\right]$} & 0.73 & 0.73 & Linear \\
\hline $\mathrm{e}_{31}$ & {$\left[\mathrm{C} / \mathrm{m}^{2}\right]$} & -0.49 & -0.49 & Linear \\
\hline $\mathrm{e}_{15}$ & {$\left[\mathrm{C} / \mathrm{m}^{2}\right]$} & -0.4 & -0.4 & Linear \\
\hline $\mathrm{C}_{11}$ & {$[\mathrm{GPa}]$} & 367 & 223 & Linear \\
\hline $\mathrm{C}_{12}$ & {$[\mathrm{GPa}]$} & 135 & 115 & Linear \\
\hline $\mathrm{C}_{13}$ & {$[\mathrm{GPa}]$} & 103 & 92 & Linear \\
\hline $\mathrm{C}_{33}$ & {$[\mathrm{GPa}]$} & 405 & 224 & Linear \\
\hline $\mathrm{C}_{44}$ & {$[\mathrm{GPa}]$} & 95 & 48 & Linear \\
\hline
\end{tabular}

For polarization-induced charge calculation, we have used the model developed by Romanov et al. 40 This model computes the polarization difference at the hetero-interface along the semipolar direction as:

$$
\Delta P=P_{L z^{\prime}}^{p z}+\left(P_{L}^{s p}-P_{T}^{s p}\right) \cos \vartheta
$$

where $P_{L}^{s p}$ and $P_{T}^{s p}$ are the spontaneous polarizations in the grown layer and substrate, respectively. $\vartheta$ is the inclination angle of the c-axis relative to the normal of the heterointerface. $P_{L z^{\prime}}^{p z}$ is the strain-induced piezoelectric polarization component of the layer defined as:

$$
\begin{aligned}
& P_{L z^{\prime}}^{p z}=e_{31} \cos \vartheta \varepsilon_{x^{\prime} x^{\prime}} \\
& \quad+\left(e_{31} \cos ^{3} \vartheta+\frac{e_{33}-e_{15}}{2} \sin \vartheta \sin 2 \vartheta\right) \varepsilon_{y^{\prime} y^{\prime}} \\
& \quad+\left(\frac{e_{33}+e 15}{2} \sin \vartheta \sin 2 \vartheta+e_{33} \cos ^{3} \vartheta\right) \varepsilon_{z^{\prime} z^{\prime}} \\
& +\left(\left[e_{31}-e_{33}\right] \cos \vartheta \sin 2 \vartheta+e_{15} \sin \vartheta \cos 2 \vartheta\right) \varepsilon_{y^{\prime} z^{\prime}}
\end{aligned}
$$

where $e_{i j}$ and $\varepsilon_{i j}$ are the piezoelectric and strain coefficients, respectively. Figure 16 shows the coordinate systems used for this calculation, as well as the obtained hetero-interface polarization difference $(\Delta P)$ as a function of the inclination angle $\vartheta$ for a strained $\operatorname{In}_{0.3} \mathrm{Ga}_{0.7} \mathrm{~N}$ layer on top of a GaN layer.
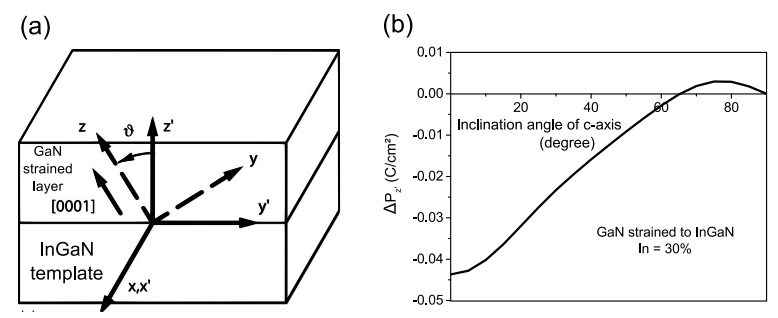

Figure 16: (a) Coordinate systems and (b) polarization difference at the hetero-interface as a function of the inclination angle of the c-axis $(\mathrm{z})$ with respect to the normal at the interface ( $\left.\mathrm{z}^{\prime}\right)$.

\section{Experiment}

InGaN NP were grown by MOVPE on top of a n-doped GaN patterned template with holes having a diameter of $100 \mathrm{~nm}$ (see Figure 14.(a)). Prior to the InGaN growth a $20 \mathrm{~nm}$ thick GaN layer was grown at $1000^{\circ} \mathrm{C}$. A $150 \mathrm{~nm}$ thick pdoped GaN layer followed by a $50 \mathrm{~nm}$ thick $\mathrm{p}^{+}$doped GaN were grown at $850^{\circ} \mathrm{C}$ on top of the InGaN NP. Further details of growth are published elsewhere. ${ }^{41}$ Contacting was made using liftoff. First the p-type contacts were defined so that the contact pad was on the $\mathrm{SiO}_{2}$ layer with a bus bar running to the exposed p-type GaN. $10 \mathrm{~nm}$ of $\mathrm{Ni}$ and $20 \mathrm{~nm}$ of $\mathrm{Au}$ were evaporated to use as the contact. The resulting structure was lifted-off and then annealed at $500^{\circ} \mathrm{C}$ for 80 seconds under $\mathrm{N}_{2}$ in a rapid thermal anneal- 
ing system to promote ohmic contact. The ntype GaN metal contacts were evaporated using $\mathrm{Ti} / \mathrm{Al} / \mathrm{Ti} / \mathrm{Au}$ with thicknesses of $8,25,10$, and $100 \mathrm{~nm}$ respectively. The SEM image of the final device is shown in the inset of Figure 14.(b).

\section{Acknowledgements}

This study has been co-funded by the French National Research Agency (ANR) under the NOVAGAINS (Grant ANR-12-PRGE-001402) project and GANEX Laboratory of Excellence (Grant ANR-11-LABX-0014) project, and French PIA project Lorraine Universite d'Excellence (Grant ANR-15-IDEX-04-LUE).

\section{References}

1. Bhuiyan, A. G.; Sugita, K.; Hashimoto, A.; Yamamoto, A. InGaN solar cells: Present state of the art and important challenges. IEEE J. Photovoltaics 2012, 2, 276-293.

2. El Gmili, Y.; Orsal, G.; Pantzas, K.; Moudakir, T.; Sundaram, S.; Patriarche, G.; Hester, J.; Ahaitouf, a.; Salvestrini, J.; Ougazzaden, a. Multilayered InGaN/GaN structure vs. single InGaN layer for solar cell applications: A comparative study. Acta Mater. 2013, 61, 6587-6596.

3. Zhao, W.; Wang, L.; Wang, J.; Hao, Z.; Luo, Y. Theoretical study on critical thicknesses of InGaN grown on (0001) GaN. J. Cryst. Growth 2011, 327, 202-204.

4. Holec, D.; Costa, P. M. F. J.; Kappers, M. J.; Humphreys, C. J. Critical thickness calculations for InGaN/GaN. J. Cryst. Growth 2007, 303, 314-317.

5. Jani, O.; Honsberg, C.; Asghar, A.; Nicol, D.; Ferguson, I.; Dwliffle, A.; Kurtz, S. Characterization and analysis of InGaN photovoltaic devices. Conference Record of the Thirty-first IEEE Photovoltaic Specialists Conference. 2005, 37-42.

6. Arif, M.; Elhuni, W.; Streque, J.; Sundaram, S.; Belahsene, S.; El Gmili, Y.; Jordan, M.; Li, X.; Patriarche, G.; Slaoui, A. et al. Improving InGaN heterojunction solar cells efficiency using a semibulk absorber. Sol. Energy Mater. Sol. Cells 2017, 159, 405-411.

7. Young, N. G.; Farrell, R. M.; Hu, Y. L.; Terao, Y.; Iza, M.; Keller, S.; DenBaars, S. P.; Nakamura, S.; Speck, J. S. High performance thin quantum barrier InGaN/GaN solar cells on sapphire and bulk
(0001) GaN substrates. Appl. Phys. Lett. 2013, 103, 173903.

8. Neufeld, C. J.; Toledo, N. G.; Cruz, S. C.; Iza, M.; DenBaars, S. P.; Mishra, U. K. High quantum efficiency InGaN/GaN solar cells with $2.95 \mathrm{eV}$ band gap. Appl. Phys. Lett. 2008, 93, 10-13.

9. Mukhtarova, A.; Valdueza-Felip, S.; Redaelli, L.; Durand, C.; Bougerol, C.; Monroy, E.; Eymery, J. Dependence of the photovoltaic performance of pseudomorphic InGaN/GaN multiple-quantumwell solar cells on the active region thickness. Appl. Phys. Lett. 2016, 108.

10. El-Huni, W.; Migan-Dubois, A.; Djebbour, Z.; Voss, P. L.; Salvestrini, J. P.; Ougazzaden, A. Optimization of semibulk InGaN-based solar cell using realistic modeling. Sol. Energy 2017, 157, 687-691.

11. Liou, B. W. Design and fabrication of In $x$ Ga 1 x N / GaN solar cells with a multiple-quantum-well structure on SiCN / Si ( 111 ) substrates. Thin Solid Films 2011, 520, 1-7.

12. Wierer, J. J.; Li, Q.; Koleske, D. D.; Lee, S. R.; Wang, G. T. III-nitride coreshell nanowire arrayed solar cells. Nanotechnology 2012, 23.

13. Dong, Y. J.; Tian, B. Z.; Kempa, T. J.; Lieber, C. M. Coaxial Group III- Nitride Nanowire Photovoltaics. Nano Lett. 2009, 9, 2183-2187.

14. Zubia, D.; Zaidi, S. H.; Brueck, S. R. J.; Hersee, S. D. Nanoheteroepitaxial growth of GaN on Si by organometallic vapor phase epitaxy. Appl. Phys. Lett. 2000, 76, 858-86.

15. Sundaram, S.; Puybaret, R.; El Gmili, Y.; Li, X.; Bonanno, P. L.; Pantzas, K.; Orsal, G.; Troadec, D.; Cai, Z.-H.; Patriarche, G. et al. Nanoscale selective area growth of thick, dense, uniform, In-rich, InGaN nanostructure arrays on GaN/sapphire template. J. Appl. Phys. 2014, 116, 163105.

16. Sundaram, S.; El Gmili, Y.; Puybaret, R.; Li, X.; Bonanno, P. L.; Pantzas, K.; Patriarche, G.; Voss, P. L.; Salvestrini, J. P.; Ougazzaden, A. Nanoselective area growth and characterization of dislocation-free InGaN nanopyramids on AlN buffered Si(111) templates. Appl. Phys. Lett. 2015, 107.

17. Ko, Y. H.; Kim, J. H.; Gong, S. H.; Kim, J.; Kim, T.; Cho, Y. H. Red emission of InGaN/GaN double heterostructures on GaN nanopyramid structures. ACS Photonics 2015, 2, 515-520.

18. Magnusson, R.; Wang, S. S. New principle for optical filters. Appl. Phys. Lett. 1992, 61, 1022-1024. 
19. Dahal, R.; Li, J.; Aryal, K.; Lin, J. Y.; Jiang, H. X. InGaN/GaN multiple quantum well concentrator solar cells. Appl. Phys. Lett. 2010, 97, 073115.

20. Young, N. G.; Perl, E. E.; Farrell, R. M.; Iza, M.; Keller, S.; Bowers, J. E.; Nakamura, S.; DenBaars, S. P.; Speck, J. S. High-performance broadband optical coatings on InGaN/GaN solar cells for multijunction device integration. Appl. Phys. Lett. 2014, 104, 163902 .

21. El-Huni, W.; Migan, A.; Alamarguy, D.; Djebbour, Z. Modeling of InGaN/Si tandem cells: comparison between 2-contacts/4-contacts. EPJ Photovoltaics 2017, 8, 85502 .

22. Kelzenberg, M. D.; Putnam, M. C.; TurnerEvans, D. B.; Lewis, N. S.; Atwater, H. A. Predicted efficiency of Si wire array solar cells. Conf. Rec. IEEE Photovolt. Spec. Conf. 2009, 001948 001953 .

23. Fabien, C. A. M.; Member, S.; Moseley, M.; Gunning, B.; Doolittle, W. A.; Member, S.; Fischer, A. M.; Wei, Y. O.; Ponce, F. A. Simulations, Practical Limitations, and Novel Growth Technology for InGaN-Based Solar Cells. IEEE Journal of Photovoltaics. 2014, 4, 601-606.

24. Li, Z. Q.; Lestradet, M.; Xiao, Y. G.; Li, S. Effects of polarization charge on the photovoltaic properties of InGaN solar cells. Phys. Status Solidi Appl. Mater. Sci. 2011, 208, 928-931.

25. Chang, J.-Y.; Kuo, Y.-K. Simulation of N-face InGaN-based p-i-n solar cells. J. Appl. Phys. 2012, 112, 033109.

26. Dickerson, J.; Pantzas, K.; Moudakir, T.; Ougazzaden, A.; Voss, P. L. Modeling of polarization effects on n-GaN/i-InGaN/p-Gan solar cells with ultrathin GaN interlayers. Opt. Quantum Electron. 2013, 45, 681-686.

27. Nasser, N.; Zhen, Y.; Jiawei, L.; Bou, X. GaN Heteroepitaxial Growth Techniques. J. Microwaves Optoelectron. 2001, 2, 16-18.

28. Elwell, D.; Elwell, M. M. Crystal growth of gallium nitride. Prog. Cryst. Growth Charact. 1988, 17, 5378.

29. Walle, C. G. V. D.; Stampfl, C. Theory of doping and defects in III V nitrides. J. Cryst. Growth 1998, 190, 505-510.

30. Pantha, B. N.; Wang, H.; Khan, N.; Lin, J. Y.; Jiang, H. X. Origin of background electron concentration in InxGa 1-xN alloys. Phys. Rev. B - Condens. Matter Mater. Phys. 2011, 84, 1-6.
31. Meillaud, F. A.; Shah, A.; Droz, C.; Miazza, C. Efficiency limits for single-junction and tandem solar cells. Solar Energy Materials and Solar Cells 2006, 2952-2959.

32. Brown, G.; Ager, J.; Walukiewicz, W.; Wu, J. Finite element simulations of compositionally graded InGaN solar cells. Sol. Energy Mater. Sol. Cells 2010, 94, 478-483.

33. Adachi, S. Physical properties of III- $V$ semiconductor compounds : InP, InAs, GaAs, GaP, InGaAs, and InGaAsP; New York: Wiley, 1992; "A WileyInterscience publication.".

34. Yang, K.; East, J. R.; Haddad, G. I. Numerical modeling of abrupt heterojunctions using a thermionic-field emission boundary condition. Solid. State. Electron. 1993, 36, 321-330.

35. El-Huni, W.; Migan, A.; Djebbour, Z.; Salvestrini, J.-P.; Ougazzaden, A. High-efficiency indium gallium nitride/Si tandem photovoltaic solar cells modeling using indium gallium nitride semibulk material: monolithic integration versus 4-terminal tandem cells. Prog. Photovoltaics Res. Appl. 2016,

36. Islam, M. R.; Kaysir, M. R.; Islam, M. J.; Hashimoto, A.; Yamamoto, A. MOVPE Growth of InxGa1xN (x 0.4) and Fabrication of Homojunction Solar Cells. J. Mater. Sci. Technol. 2013, 29, 128-136.

37. Moses, P. G.; Van De Walle, C. G. Band bowing and band alignment in InGaN alloys. Appl. Phys. Lett. 2010, 96, 2-5.

38. Yam, F.; Hassan, Z. InGaN: An overview of the growth kinetics, physical properties and emission mechanisms. Superlattices Microstruct. 2008, 43, $1-23$.

39. Ishitani, Y.; Xu, K.; Che, S. B.; Masuyama, H.; Terashima, W.; Yoshitani, M.; Hashimoto, N.; Akasaka, K.; Ohkubo, T.; Yoshikawa, A. Properties of the fundamental absorption edge of InN crystals investigated by optical reflection and transmission spectra. Phys. Status Solidi Basic Res. 2004, 241, 2849-2853.

40. Romanov, A. E.; Baker, T. J.; Nakamura, S.; Speck, J. S. Strain-induced polarization in wurtzite III-nitride semipolar layers. J. Appl. Phys. 2006, 100 .

41. Sundaram, S.; Puybaret, R.; Li, X.; El Gmili, Y.; Streque, J.; Panztas, K.; Orsal, G.; Patriarche, G.; Voss, P. L.; Salvestrini, J.-P. et al. High quality thick InGaN nanostructures grown by nanoselective area growth for new generation photovoltaic 
devices. Physica Status Solidi (a) 2015, 212, 740-

744 . 